\title{
Justice, Res Publica and Empire: Subsidiarity and Hierarchy in the Roman Empire
}

\author{
Frédéric Hurlet
}

The objective of this study is to synthesize and extend research conducted in connection with the series of three international conferences held at the Villa Vigoni (Menaggio, Como) from 2010 to 2012, on the exercise of justice in the Roman Empire during the High Empire and late Antiquity. As indicated by the title chosen for the publication (Recht haben und Recht bekommen im Imperium Romanum: das Gerichtswesen der römischen Kaiserzeit und seine dokumentarische Evidenz), the purpose of these meetings was notably to underscore the wealth and diversity of documentation on the subject of judicial practice. ${ }^{1}$ With this in mind, it was less a matter of focusing on normative sources - late-antique compilations that have been amply explored since the nineteenth century - than of emphasizing what the large number of inscriptions and papyri discovered during the twentieth and twenty-first centuries have contributed to our knowledge of how justice operated on an everyday basis and how it was experienced by those subject to it. This work has certainly fulfilled its goal in this regard through the use of epigraphic and papyrological documents, some of which had never been published.

The Intrinsic Links between Justice and Power in Antiquity

The relative documentary abundance on the exercise of justice in the Roman Empire is in truth not surprising. It is a consequence of the central role that justice, as well as the functioning of the judiciary institutions tasked with applying law, played in the everyday life of the Empire's inhabitants, whether in a global (imperial) or local setting (on the level of the different types of communities that formed the Empire's base units). There is hardly a need

1 R. Haensch (ed.), in collaboration with Fr. Hurlet, S. Strassi, K.-L. Link, and A. Teichgräber, Recht haben und Recht bekommen im Imperium Romanum. Das Gerichtswesen der römischen Kaiserzeit und seine dokumentarische Evidenz, The Journal of Juristic Papyrology Supplement 24 (Warsaw 2016). 
to point out that those who exercised one form of power or another in the Roman Empire were all involved in judiciary duties, to such an extent that they undoubtedly devoted the greater part of their time and energy to it. This reality has already been assessed for imperial service, which was classified as an "occupation" and considered the princeps as a full-fledged judge from the Principate of Augustus onward. ${ }^{2}$ During the same period, the Senate transformed into a court of law. ${ }^{3}$ In the provinces, governors were "overwhelmed" by pressure from the many requests submitted by those subject to the laws, ${ }^{4}$ so much so that a complex system of delegation was implemented, which took the form of initial filters and referral to other jurisdictions. Furthermore, the Romans did not have a monopoly over justice and jurisdictional activity, notably because Roman authorities and their courts could not absorb the large body of cases emanating from the entire imperial space. As a result, one must also take into account local jurisdictions that were active in both Italy and the provinces, to which surviving municipal laws devote a number of chapters. $^{5}$

Such a "mosaic" of courts was absolutely necessary. On the scale of the Roman Empire, it was one of the obligatory forms taken by the exercise of power, which the governed expected to render justice: this is illustrated by the well-known anecdote of a woman who scolded both the Greek king and the Roman emperor - in this case Hadrian - because he did not have time for her case, thereby calling into question the legitimacy of a power that neglected those accountable to its laws, even the most modest. ${ }^{6}$ As a form of power, the imperium populi Romani was thus inseparable from the exercise of justice, one that had to be exerted across the entire imperial territory and that was inconceivable without the operation of judicial practice, regardless of locale or level. If we extend this reasoning, justice becomes one of the instruments used by

2 Cf. F. Millar, 'Emperor at work', Journal of Roman Studies 57 (1967), 9-19 (= F. Millar, The Greek World and the East II, Government, Society and Culture in the Roman Empire, ed. by H.M. Cotton and G.M. Rogers (Chapel Hill, London 2004), 3-22) and F. Millar, The Emperor in the Roman World (London 1977), passim.

3 On this subject see Fr. Hurlet, 'Les origines de la juridiction impériale: Imperator Caesar Augustus iudex', in: Haensch 2016, op. cit. (n. 1), 16-18.

4 R. Haensch, 'Des empereurs et des gouverneurs débordés', Cahiers du Centre Gustave Glotz 19 (2008), 177-186.

5 On this subject see the contribution of the lex Irnitana to our understanding of the subject.

6 On the subject of Hadrian see Cassius Dio 69.6.3: 'At any rate, once, when a woman made a request of him as he passed by on a journey, he at first said to her, 'I haven't time', but afterwards, when she cried out, 'Cease, then, being emperor,' he turned about and granted her a hearing'. 
Rome to keep a grip over its Empire, as well as one of the primary operating methods of that Empire, in much same way as the army, the census, or taxation. ${ }^{7}$ the Imperial Period: Subsidiarity and Hierarchy

The Roman emperor was in theory the supreme judge: he had issued decisions on first hearing since the Principate of Augustus, ${ }^{8}$ and was gradually recognized as having a right of appeal that enabled him to serve as an appellate judge. ${ }^{9}$ Yet this general and even universal overview leaves a number of chronological and practical difficulties in the dark. It should firstly be pointed out, with regard to the now-dominant position, that the right to issue judgments on appeal in the context of appellate procedure was not granted to the princeps from the beginning, a point to which I will return. It should also be emphasized that imperial power strictly speaking could not exercise its occupation as full-fledged judge in a uniform way across the scale of an Empire numbering dozens of millions of inhabitants. The anecdote of the woman reproaching Hadrian says a great deal about the judicial expectations of those subject to its laws, but in practice these expectations could be met only if the princeps was accessible, that is to say primarily in Rome or wherever he went during his tours of the provincesan itinerant practice of which the frequency varied depending on the emperor.

Given these conditions, Roman authorities implemented a system of delegation based on two complementary principles, which were the key to the whole system. The first is subsidiarity, which helped a potentially congested imperial judicial machine function more fluidly by allowing local authorities to judge local cases of lesser importance, with no need to call on a superior bodyan opportunity seized by local jurisdictions. ${ }^{10}$ The second is the uncontestable

7 On the concrete manifestations of Roman administrative activity including justice, see Fr. Hurlet, 'Introduction. Gouverner l'Empire: les modalités de l'emprise de Rome sur l' Occident', in: Fr. Hurlet (ed.), Rome et l'Occident (II siècle av.J.-C.-II siècle ap.J.-C.). Gouverner l'Empire (Rennes 2009), 18.

8 On this subject see Hurlet 2016, op. cit. (n. 3), 18-29; see also K. Tuori, The Emperor of Law: the Emergence of Roman Imperial Adjudication (Oxford 2016).

9 On this subject see Fr. Hurlet, 'Entre juridiction civique et juridiction impériale. La sphère de compétences du proconsul', in: Haensch 2016, op. cit. (n. 1), 71-72 and 76-87.

10 For an application of the principle of subsidiarity in the Roman Empire, see the illuminating remarks by J.-L. Ferrary in an interview published in Figaro Histoire, April-May 2017: 'Une dernière remarque sur ces cités grecques dans l'Empire, c' est leur formidable 
principle of hierarchy, ${ }_{1}^{11}$ which considered Roman law as the law of reference superior to all others, and resulted in a functioning pyramidal system based on the distinction between what local courts adjudicated and what came under the jurisdiction of Roman courts. From this point of view, the central problem was to connect the different jurisdictions: local justice and Roman justice on the one hand, and with respect to Roman justice, imperial power and various provincial Roman authorities on the other, for instance that of the governor. In the end, the Roman judicial machine of the imperial period proved to be flexible enough to operate on a daily basis, but also highly unequal, for accessing Roman justice required the person subject to trial to have sufficient financial means for travel, as well as the required aristocratic networks in a world characterized by the importance of personal relations.

\section{The Division between Different Jurisdictions: The Norms}

Research has made progress on this question over the last decade, partly thanks to the work of Julien Fournier. His monograph on "judicial administration" in Continental Greece and the province of Asia during the Roman period is now considered as a point of reference, but he also took an interest in the provinces of the Roman West. ${ }^{12}$ Among the findings of these studies was the demonstration that the fundamentally hierarchical and unequal character of the exercise of Roman justice, which hardly disappeared with the creation of the Principate by Augustus, was reconfigured with the change in political system. A crucial evolution was the granting of access to Roman courts not just

capacité à résoudre sur place, en interne, ce qui peut l'être avant d'interpeller une instance supérieure, le gouverneur de la province. Une sorte de principe de subsidiarité qui est valable, cependant, pour tout l'Empire'.

11 Regarding hierarchy as a principle of government under the High Empire, including its methods and how it was connected to the principle of delegating authority, I would refer readers to a study conceived as a synthesis: Fr. Hurlet, 'Les modalités de la hiérarchie et de la délégation. Les rituels de médiation entre le prince et le gouverneur sous le HautEmpire romain', in: A. Bérenger and Fr. Lachaud (eds.), Hiérarchie des pouvoirs, délégation de pouvoir et responsabilité (Metz 2012), 161-177.

12 J. Fournier, 'Rome et l' administration judiciaire provinciale', in: Fr. Hurlet (ed.), Rome et l'Occident (II siècle av. J.-C.-II siècle ap. J.-C.). Gouverner l'Empire (Rennes 2009), 207227; J. Fournier, Entre tutelle romaine et autonomie civique. L'administration judiciaire dans les provinces hellénophones de l'Empire romain (129 av. J.-C.-235 apr. J.-C.) (Athens 2010); J. Fournier, 'L' administration de la justice dans le monde romain. $\mathrm{I}^{\mathrm{er}}$ siècle av. J.-C.- $\mathrm{I}^{\mathrm{er}}$ siècle ap. J.-C., in: N. Mathieu (ed.), Le monde romain de 70 av. J.-C. à 73 ap. J.-C. Voir, dire, lire l'empire, (Rennes 2014), 171-208. 
on the criterion of possessing Roman citizenship, but also based on the legal classification of the case being adjudicated. Civil jurisdictions were set aside in favor of Roman jurisdictions for trials falling under criminal law, regardless of the status of the individuals involved. The same was true for financial disputes under civil law that surpassed a certain amount. One can cite a number of cases that fell under the jurisdiction of Roman law due to the nature of the case.

3.1 The Edict of Cyrene

The first evidence of this reconfiguration of the courts on the scale of the full Empire appeared during the Principate of Augustus in the 4th Edict of Cyrene, which set apart those accused of a capital crime, "for whom the governor of the province is required to either investigate and judge himself, or to gather a jury (consisting of Romans and peregrini)". ${ }^{13}$

\subsection{Edict of M. Petronius Mamertinus}

Another record suggesting the same, this time a papyrus dating from the Principate of Hadrian, is the edict by a prefect in Egypt named M. Petronius Mamertinus, who provided a list of matters, most likely taken from an imperial constitution, that the governor had to investigate by way of a cognitio: cases involving murder, robbery, poisoning, abduction, livestock theft, armed violence, forgery and false testimony, premature opening of wills, serious offenses, and complaints by patrons against their freed slaves as well as parents against their children. A final category was added with regard to appeals, specifying that those who made recourse to this law would be heard only if they left a security deposit equal to a quarter or a third of the amount involved in the matter to be adjudicated. ${ }^{14}$

\subsection{Lives of the Sophists by Philostratus}

A third document to include is an excerpt from the Lives of the Sophists by Philostratus, which put in the mouth of the sophist Polemon of Smyrna words that distinguish between trials "for money" that were likely to be adjudicated by a

13 E-J, n ${ }^{\circ} 311=$ J.H. Oliver, Greek Constitutions of Early Roman Emperors from Inscriptions and Papyri (Philadelphia 1989), n 8-11 = R.K. Sherk, Roman Documents from the Greek East. Senatusconsulta and Epistulae to the age of Augustus (Baltimore 1969), n ${ }^{\circ}$ 31, l. 65-66; cf. F. De Visscher, Les édits d'Auguste découverts à Cyrène (Leuven 1940), 62-69.

$14 S B$ XII 10929; on this text see A. Jördens, 'Eine kaiserliche Konstitution zu den Rechtsprechungskompetenzen der Statthalter', Chiron 41 (2011), 327-355; Eadem, 'Die Strafgerichtsbarkeit des Praefectus Aegypti', in: Haensch 2016, op. cit. (n. 1), 93-94. 
civic court, and other trials falling under the jurisdiction of a judge possessing the ius gladii, in this case the governor, such as cases of adultery, sacrilege, and murder. ${ }^{15}$

\subsection{Lex Irnitana, lex Rubria, Fragmentum Atestinum}

With regard to cases for money, to use the expression of Philostratus, we know from a number of other texts that for each city there was a financial limit below which the governor did not intervene, and for which we have a number of examples: 1,00o sesterces for the city of Irni in Baetica (art. 84);16 10,000 or 15,000 sesterces for the cities of Cisalpine Gaul, with the praetor of Rome handling cases above this amount. ${ }^{17}$

A consequence of the new jurisdictional division was that peregrini could henceforth be judged by Roman judges, regardless of whether this was in their interest or to their detriment. It consequently helped create a new consensus that united the governors and the governed, and formed one of the bonds within the Roman Empire. It did so by presenting Roman authority, especially that of the emperor and the governor, not as an external authority but as the highest and most legitimate of jurisdictions, in short as the judicial authority of reference. ${ }^{18}$ The real or at the very least potential presence of Roman jus-

15 Philostratus, Life of the Sophists, 1.25.2 (532): 'The suits which they brought against one another he did not allow to be carried anywhere abroad, but he would settle them at home. I mean the suits about money, for those against adulterers, sacrilegious persons and murderers, the neglect of which breeds pollution, he not only urged them to carry them out of Smyrna but even to drive them out. For he said that they needed a judge with a sword in his hand.'

16 See F. Lamberti, Tabulae Irnitanae. Municipalità e ius Romanorum (Naples 1993) and Idem, 'La giurisdizione nei municipia dell'occidente romana e il cap. 84 della lex Irnitana', in: Haensch 2016, op. cit. (n. 1), 183-211.

17 Regarding the lex Rubria, which is dated $41 \mathrm{BCE}$, and Cisalpine Gaul (which had been attached to Italy in 42 BCE), see M.H. Crawford, ed., Roman Statutes (London 1996), 1, 28, chap. 22; see also the Fragmentum Atestinum, which mentions an amount of 10,00o sesterces for the late Republican period (Crawford 1996, op. cit., n. 14, I, 16, col. I 6).

18 On this subject see C. Ando, Imperial Ideology and Provincial Loyalty in the Roman Empire (Berkeley, Los Angeles, London 200o) and Idem, 'La forme canonique de l' empire antique: le cas de l' Empire romain', Ius Politicum. Revue de droit politique 14 (2015): http://juspolitic um.com/article/La-forme-canonique-de-l-empire-antique-le-cas-de-l-empire-romain972.html. 
tice throughout the imperial space, along with its accessibility to all free men living within that space, were the institutional facts that contributed the most toward making the Roman Empire a reality experienced on a daily basis by all of its inhabitants.

The notion of consensus, which was expressed in the Roman Empire through reference to the consensus uniuersorum, should certainly not be underestimated or disqualified on the pretext that it was no more than a source-based (re)construction seeking to establish order in a naturally conflictual world, to "create a shared direction" in Claudia Moatti's fine phrase. ${ }^{19}$ It should instead be presented as an ideal that imperial authorities sought to apply in the exercise of justice, and one that consequently had concrete repercussions. Yet it is also true that acceptance of Roman presence and justice resulted from a process that was under permanent (re)negotiation. While the redistribution of judicial roles helped to better integrate all of the provinces within the imperial space, it fell far short of resolving all problems. It led to new difficulties of a practical nature, which were essentially caused by the increased pressure exerted on Roman courts by those subject to its jurisdiction, who sought out the jurisdiction that would prove the most favorable to them. A distinction should therefore be made between the consensus as it was presented and sought by imperial authorities, and the consensus as it was perceived and used by the governed.

The superimposition of Roman justice on local civic justice had an immediate and natural consequence: those governed by it, and likely to be subject to it, developed individual strategies for making recourse to a Roman justice whose disconnection from the local context supposedly made it impartial, or at least less partial. The reconfiguration of different jurisdictions on the level of the Roman Empire as sketched out above is indeed theoretical. It could not always resist the reality on the ground, which was expressed through power relations between individuals subject to the laws, a reality that could prompt Roman authorities to intervene on the local judicial scene.

An example involving a remarkable case is that of a couple of citizens from Knidos, named Euboulos and Tryphera, who during the final decade BCE

19 C. Moatti, 'Historicité et 'alteronomie': un autre regard sur la politique', Politica antica 1 (2011), 108; see also now C. Moatti, Res publica. Histoire romaine de la chose publique (Paris, 2018), passim. 
fled for Rome after one of their slaves killed-accidentally according to the couple - a free man also named Euboulos during a night-time disturbance of the peace. The homicide took place in a free city, which meant that there was a civic court in Knidos, one that was authorized to deliver and execute a death penalty verdict against its citizens condemned for murder. We know nothing of the local context during this period, but the fact that the couple preferred to leave Knidos and go halfway across the Mediterranean to take refuge in the Empire's capital says a great deal about the risks they believed they ran in their city, as well as the lack of confidence they had in the local court. One must suppose that the aristocratic alliance networks present in the city of Knidos locally played out against Euboulos and Tryphera and in favor of their adversaries. The case did not end there. Ambassadors from Knidos were sent to Rome to give Augustus a decree from their city and to accuse in his presence both Euboulos, who had died in the meantime, and Tryphera. The decision of the princeps was unambiguous: he exculpated the couple, affirming that they had "committed no injustice," and ascribed the fault to those who had disturbed the peace by annoying Euboulos and Tryphera at night in front of their house. Not everything is clear in the case, although the great visibility of Augustus was an unquestionable reality, as was the drawing power of the imperial court that stemmed from this visibility. These were so many elements that prompted a couple from Knidos to go to Rome, knowing that they would find a court of law that was supposed to be more favorable, or in any case less unfavorable than the local civic court. Furthermore, from a hierarchical point of view, this court was the highest jurisdiction, against which there could be no recourse. ${ }^{20}$

The case of Euboulos and Tryphera is an example that most probably was not an isolated case. Of course not everyone subject to the laws had the financial and logistical means to go to Rome, or to wherever the princeps was when away from Rome, something that occurred quite often during the first half of the Principate of Augustus. Imperial authority had nevertheless become a point of convergence on the scale of the Empire, so much so that the strategic circumvention of the local civic court took place on other occasions. It is unfortunately difficult to evaluate how frequently this practice took place, due to the small number of sources on the subject: the traditional and ephemeral mediums

20 This inscription, which has been known since the nineteenth century, was the subject of a useful publication in Sherk 1969, op. cit. (n. 13), n 67, 341-345 (with an exhaustive bibliography for the period); see also E-J, 312 and, more recently, Oliver 1989, op. cit. (n. 13), $\mathrm{n}^{\circ}$ 6, 34-39; W. Blümel, Die Inschriften von Knidos I, IK 41 (Berlin 1992), $\mathrm{n}^{\circ} 34,34-37$, and V. Wankerl, Appello ad Principem. Urteilsstil und Urteilstechnik in kaiserlichen Berufungsentscheidungen (Augustus bis Caracalla) (Munich 2009), 3-4. 
for administrative communication were written on papyrus or wood, which explains for example why we have good information in the case of Egypt. The continual discovery of papyri has helped improve our knowledge of judiciary practices in this province, although the documentary situation for the remainder of the Empire is less favorable. The letter from Augustus to the city of Knidos is an exception in this regard, and one that is difficult to explain. It was discovered in the neighboring city of Astypalaea, which was a free city like Knidos, although we do not clearly understand the reasons for its presence there, a central element in explaining its unusual engraving on a lasting material. ${ }^{21}$

The case of Tryphera raises the potential of another problem, namely the risk of Roman courts being congested by requests from Italians or members of the provinces potentially tempted to bypass local authorities when it suited them. Whatever its form, Roman authority gained legitimacy in presenting the image of an accessible judicial authority, and in making the exercise of justice an activity that stemmed from the exercise of imperium. Over time, however, it had to absorb the large number of cases that presumably reached it, as well as the large amount of information that had to be mastered to render an equitable judgment in each of the cases. This practical difficulty was true not only for an imperial power that was in theory active across the entire imperial space, but also for Roman authorities acting in the provinces, most of which were quite large. This challenge became even more acute with the implementation of the right of appeal, which naturally prompted those individuals whose case was dismissed, or who were condemned on first hearing by a local civic jurisdiction, to call on Roman authorities to be judged anew on appeal.

The trip to Rome made by Tryphera and Euboulos took place during the Principate of Augustus, that is at a time when the new authority was becoming aware of its new judicial attractiveness on the scale of the Empire and exploring its repercussions. The date of this case $-6 \mathrm{BCE}-$ makes the notion that Augustus rendered an appeal judgment on this occasion unlikely, for this procedure appeared on a regular basis beginning with the Principate of Claudius. In any event, the system was initially quite empirical, a reality that explains why the approach taken by the couple from Knidos was successful before Augustus. This situation, however, did not last, for it ran the risk of bombarding imperial authorities with similar requests. In any case, it was probably to avoid the risk of congesting Roman courts that Roman authorities put in place a system of filters, the first clear evidence of which can be found in a fragmentary letter

21 On the different explanations possible, see my analysis in Hurlet 2016, op. cit. (n. 3), 19, n. 37 . 
dating from the Principate of Claudius that was addressed by the proconsul of Asia, Cn. Domitius Corbulo, to the city of Kos. ${ }^{22}$ What this document teaches us, among other things, are two important elements for this demonstration: first, in a case involving an individual from the provinces, the grounds for the appeal must be examined by the governor before being transmitted to the princeps; ${ }^{23}$ second, a security deposit to the substantial amount of 2,500 denarii had to be paid to the governor for any appeal appearing before his jurisdiction, so as to limit the number of pleas. As a result, a pyramidal structure emerged for a jurisdiction based on both incontestable hierarchy (ranging from the local civic jurisdiction to that of the provincial governor and ultimately imperial jurisdiction) and the implementation of safeguards, in order to prevent the system from being a victim of its own success or of the strategies used by those subject to the laws, who tried to take advantage of the system and its flaws to cast a favorable light on their case.

If you look closely, the situation revealed by the letter of the proconsul of Asia to the city of Kos is in substance very similar to the approach taken half a century earlier by the couple from Knidos, although the resulting decision was different. This letter was justified as a reaction to the stance taken by a citizen of Kos, whose name we do not know, but who seems to have brought an appeal directly to the Emperor Claudius after a decision against him by the city, and who did so without obtaining the agreement of the proconsul in advance. Even though the appeal most likely did not exist as an official procedure during the first half of the Principate of Augustus, Euboulos and Tryphera acted in a similar way by going directly to the princeps without seeking out the proconsul beforehand. At the time this was probably C. Asinius Gallus (consul 8BCE and proconsul of Asia in 6/5 BCE), who at the request of Augustus subsequently intervened in Knidos to conduct a complementary investigation. It should be pointed out that these citizens of Knidos and Kos were all from a free city, although the similarities end there. What was in fact possible and successful during the time of Augustus proved problematic approximately fifty years later: it was not that seeking out the princeps directly was impossible - the exact opposite is true, as we know that a citizen of Kos

22 The letter, which consists of three fragments, is damaged on its left side. The edition of reference is now $I G$ XII, 4, 261 [2010], although we will continue to consult the earlier editions of J.H. Oliver, 'Greek Applications of Roman Trials', American Journal of Philology 100 (1979), 551-554, and M. Segre, Le iscrizioni di Cos I (Rome 1993), no. 43, which have proposed different restitutions for lines 4-10, none of which clearly asserts itself.

23 See lines 13-16, which present no problems in establishing the text: $\Delta \dot{\varepsilon} /[$ ov $\tau]$ oívov, हi่ $\mu \dot{\varepsilon} v$

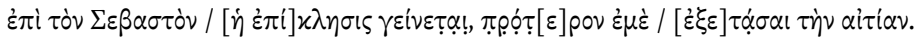


sought Claudius directly - but that this approach was explicitly condemned. We do not know what came of the appeal brought by the anonymous citizen of Kos.

The very necessity for the proconsul of Asia to have to write a letter pointing out that no appeal could reach the princeps without his approval indicates that the pyramidal character of Roman jurisdiction was not a foregone conclusion for everyone. This was true for two reasons, which are not necessarily exclusive, and can be combined. First, one may suppose that such an obligation had just been implemented through the introduction or widespread availability of a right of appeal under the Principate of Claudius, a right that naturally had to spread so that people in the provinces who were subject to the law were informed thereof. Second, the very existence of the letter of the proconsul of Asia proves that in contrast to practice, it was simply impossible for a governor to prevent one of his citizens from seeking out the princeps, all the more so if it involved a case in which the provincial individual subject to trial had nothing to lose. This reality thus suggests that the imperial judicial system should not be considered as a structure that was bureaucratic and fixed, but rather one marked by a flexibility specific to the imperial constructions that preceded the modern form of the nation state. The categories in book XLIX of the Digest, which discusses the appellatio, solidify the situation. They refer to a rescript by Marcus Aurelius and Lucius Verus, according to which "appeals addressed directly to the emperor-and ignoring those before whom lower-level appeals had to be brought-must be sent back to the governors." 24 The existence of this normative framework should not obscure the fact that this final result was the product of an evolution, and that this rule was established to do away with potential congestion of the imperial court. ${ }^{25}$

There is perhaps a final reason why the Roman judicial system put in place a system of filters between imperial authorities and those subject to the laws: the emperor's desire to avoid directly punishing possible abuses by his own soldiers, ${ }^{26}$ and therefore to delegate to an intermediary authority, such as the governor, the power to issue a judgment without the emperor having to intervene in a potentially sensitive case. This motivation remains a possibility, ${ }^{27}$

24 Papirius Iustus Dig. 49.1.21.pr.: Imperatores Antoninus et Verus rescripserunt appellationes, quae recto ad principem factae sunt omissis his, ad quos debuerunt fieri ex imo ordine, ad praesides remitti.

25 And even then, the emperor could decide otherwise, as in the Goharian inscription (SEG 17.759).

26 See the imperial third-century decisions, as collected in T. Hauken, Petition and Response. An Epigraphic Study of Petitions to Roman Emperors, 181-249 (Bergen 1998).

I would like to thank Lukas de Blois for drawing my attention to this point. 
without for all that being certain. This possibly explains why we have no evidence of a judgment issued by the princeps regarding soldiers during the first two centuries CE, although the gaps in our documentation should also be taken into account. However, we know of a subscription by Caracalla from the Severan period regarding illegal requisitions made by soldiers to the detriment of the city and the imperial domain of Takina in Phrygia. This offers evidence that such a case was elevated to the highest judicial level of imperial authority, which condemned the Roman soldiers. ${ }^{28}$ Moreover, we know from a rescript of Severus Alexander addressed to the Greek community of Bithynia that nobody could be prevented from appealing to its judges, for everyone subject to the laws was allowed to pursue another path and seek out the princeps more quickly. This means that imperial authorities accepted to hear an appeal involving its own administration and members of its own army. ${ }^{29}$ The primary reason for the existence of this pyramidal system remains, after all, the application of what was defined at the outset as the principle of subsidiarity.

The functioning of justice on the scale of the Empire should be studied using a method that combines institutions and practices, and that does not lose sight of the fact that law was permanently tested by reality, and could partly adapt to it. ${ }^{30}$ There were norms of division between the different jurisdictions present on the scale of the Empire, which were implemented gradually and with disparities between them. The rules in effect within this domain have been studied over the course of the last decade with great acuity, however they should include an additional and more practical criterion, that of access to Roman justice, which could disturb the pyramidal arrangement of jurisdictions in both directions: either the person subject to trial was unable to go to a Roman court, whether it was that of the princeps or of the governor, with the latter being located in the provincial capital or the various headquarters of the conuentus; or he had the financial and material means to be mobile, and used them to go to one of the Roman authorities in spite of not meeting all of the legal conditions.

$28 A E, 1989,721=S E G$, XXXVII, 1186.

29 Paul. Dig. 49.1.25. The content of this rescript has also been conserved in two papyri (P. Oxy 17.2104 and 43.3106), which have gaps in addition to a few modifications as compared to the text transmitted by Paul. On this rescript of Severus Alexander see F. Nasti, L'attività normative di Severo Alessandro. I. Politica di governo. Riforme amministrative e giudiziarie (Naples 2006), 41-70. 
So far we have considered examples in which the superimposition of Roman jurisdiction on a local jurisdiction was accepted in principle, and contributed to the global consensus on the scale of the Empire. Such an acceptance was selfevident in the Latin and Roman communities of the Empire, which thought of themselves as emanations of Rome, and therefore copied Roman law by adapting it to the local setting. Citizens of such cities had their own court of law, and naturally accepted a hierarchy whose principle was to refer all cases falling under Roman jurisdiction to the higher level, whether provincial or imperial. With regard to communities of peregrini, the connection between local and imperial justice, which was hardly a novelty in the Greek world, had been tested in the past by poleis, which had already been through royal experiences, and were therefore accustomed to seeing one or more citizens call on either one of the jurisdiction depending on the case. Some people in the provinces of the Greek world perceived the advantages offered by this system, notably the existence of a right of appeal, which Aelius Aristides presented in a general manner as one of the specific features and advantages of Roman hegemony: 'How is this form (imperial) of government not beyond every democracy? There it is not possible after the verdict is given in the city to go elsewhere or to other judges, but one must be satisfied with the decision, unless it is some small city which needs outside judges. But among you now a convicted defendant or even a prosecutor, who has not won his case, can take exception to the verdict and the underserved loss. Another great judge remains, whom no aspect of justice ever escapes. And here there is a great and fair equality between weak and powerful, obscure and famous, poor and rich and noble.'. ${ }^{31}$ This stance was also expressed by a Roman authority in an inscription originating from Sparta (presumably a letter sent by the proconsul of Achaea to this city): 'it is not right, I think, for the victims of injustice to be deprived of the relief they can get by appeals.'32

There remains the case of cities of peregrini in the Roman West, which is specific because the very principle of a non-local, non-native, and superior justice system did not exist before the Roman conquest. We know that Roman justice ultimately was gradually imposed on all people in the provinces as conquered territories in the provinces were subdued, yet it was a process that required that

$31 \quad$ Éloge de Rome 26.38-39. On differences between theory and practice, see Herz in this volume.

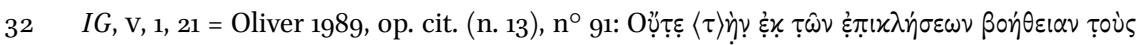

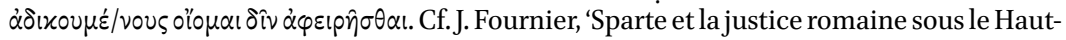
Empire. À propos de $I G \mathrm{~V}$ 1, 21', Revue des Études Grecques 118 (2005), 117-137. 
they learn Roman judicial practices. Some regions were more recalcitrant than others to this new Roman judicial practice, which disturbed age-old customary practices. The failure to establish Roman justice was one of the factors in the ultimate failure of the imperial project in the areas concerned. Germania offers an emblematic example of this, in the sense that the exercise of Roman justice was never accepted, no more so than the other indicator of imperial presence, taxation. This is what Velleius Paterculus explained in a fairly detailed passage, in which he describes the situation that preceded the rebellion of Arminius in $9 \mathrm{CE}$, and emphasizes the behavior of the Roman governor Quinctilius Varus, which was characterized by a kind of judicial mania. Quinctilius Varus was present during the period preceding the rebellion as a judge, so much so that he forgot he was also a military leader, naively believing that "the novelty of unfamiliar discipline" that Roman justice represented for the Germans would be enough to soften their savage customs. ${ }^{33}$ Beyond the moral judgment of a governor responsible for one of the worst military disasters Rome ever experienced, it is on the contrary quite possible to suppose that Roman judiciary practice, which was indeed new in Germania, broke with traditional customs that favored the resolution of conflict through private justice and arms. It was therefore not at all self-evident given how different it was from the practices used in the area at that time, and prompted distrust and even hostility. One of the numerous reasons for the ultimate failure of the Romans in Germania came down to their inability to connect their own justice with local jurisdictions, and to create, as they had elsewhere, a functional pyramidal system based on the distinction between what fell under the jurisdiction of local courts and what was a matter for Roman courts. The German reaction to the exercise of Roman justice therefore confirms that the primary difficulty in integrating them resided in the most concrete manifestations of Roman administrative activity. $^{34}$

33 Vell. 2.118.1: At illi (the Germans) ... simulantes fictas litium series et nunc prouocantes alter alterum iniuria, nunc agentes gratias quod ea Romana iustitia finiret feritasque sua nouitate incognitae disciplinae mitesceret et solita armis discerni iure terminarentur, in summam socordiam perduxere Quintilium usque eo ut se praetorem urbanum in foro ius dicere, non in mediis Germaniae finibus exercitui praeesse crederet ('But the Germans ... by trumping up a series of fictitious lawsuits, now provoking one another to disputes, and now expressing their gratitude that Roman justice was settling these disputes, that their own barbarous nature was being softened down by this new and hitherto unknown method, and that quarrels which were usually settled by arms were now being ended by law, brought Quintilius to such a complete degree of negligence, that he came to look upon himself as a city praetor administering justice in the forum, and not a general in command of an army in the heart of Germany').

On this subject see Fr. Hurlet, 'Rejeter le contrôle de Rome. Les formes de résistance 
This negative conclusion conversely reinforces the notion that the functioning of Roman justice was inseparable from the imperium exerted by the person representing Rome in the provincial territory, and as such was one of the primary hallmarks of imperial power over the space it controlled. The example of Germania - or that of Britannia-indicates that the hierarchical superimposition of Roman justice in a spirit of subsidiarity was not automatic, and had to take into account the pre-Roman context. Yet these failures should not cast a shadow over the fact that Roman justice was generally well accepted within the vast space of the Roman Empire over the long term. The chronological dimension should be taken into account here, and it should be noted that presenting a synthesis of the functioning of Roman justice during the entire three centuries of the Roman High Empire is highly difficult, if not impossible. For all that, there was an evolution toward the reinforcement of Roman justice and a general consensus regarding this process: the more time that passed, the more Roman citizens there were- until the Antoninian Constitution of 212and the more Roman justice asserted itself as a foundation of 'imperiality' to which the provinces adhered. Roman judges were subsequently considered in the provinces as a third party or an arbitrator, who was supposed to be impartial because of his distance from local events, and as such more capable of resolving internal conflicts.

It is important not to stop at a naively consensual or even irenic vision of Roman justice. Some of those subject to the law took advantage of this situation to circumvent their own law, or to delay the resolution of conflict and thereby maintain a status quo favorable to one of the two parties involved. Roman justice was first and foremost an instrument of imperial domination, for it could prove both flexible and strict in applying sentences. Furthermore, it was not always easily accessible. Individuals subject to trial had to present themselves at a Roman court, whether it was the court of the governor in their capital or the different seats of the conuentus, or directly at that the court of the princeps,

aux structures fiscales et administratives de l'Empire romain', in. S. von Reden (ed.), Ressources, environnement, échanges et pouvoir dans l'Antiquité classique, Entretiens de la Fondation Hardt 63 (Geneva 2017), 214-216 and 226-227. While the passage from Velleius Paterculus quoted in the previous note tells us more about how the Romans saw their imperialism than about how the Germans experienced Roman justice, it cannot be dismissed as a source of information: far from inventing, Velleius in fact makes a moral judgement by emphasizing the inability of the Germans to accept the greatly superior and impartial Roman justice. 
which was normally even more complicated. They also had to overcome the obstacles resulting from the filters that Roman justice put in place for those who wanted to be judged by a Roman court, in an effort to prevent congestion by a flow of requests from people in the provinces. All of these elements underscore the idea that in addition to subsidiarity, the dominant principle of Roman justice was its highly hierarchical character: from an institutional point of view, Roman jurisdiction was first and foremost the authority that applied Roman law, and as such was superior to any other jurisdiction, so much so that Roman judges ended up becoming appellate judges, whose decisions could not be challenged. With regard to practices, it was far from being accessible to everyone who was subject to the laws, and reinforced inequalities through a series of concrete factors: differentiated access to Roman justice based on greater or lesser spatial proximity to the Roman court; economic considerations, which took the tangible form of being able to pay a sizeable amount to bring an appeal before the governor or the emperor; and integration within aristocratic networks, which facilitated access to the court of the governor or that of the princeps. 